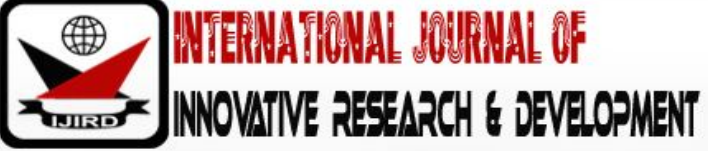

ISSN 2278 - 0211 (Online)

\section{Ghana's Growing Debt and Its Implications for the Economy}

\author{
Dr. Ebenezer M. Ashley \\ Lead Consultant, Department of Finance, Banking, Economics \& Business, \\ EBEN Consultancy, Accra, Ghana \\ Dr. Edward Kufuor \\ Chairperson, Department of Business, ASA College, New York, USA \\ Edward A. Boamah \\ Manager, Department of Insurance, Phoenix Insurance Company Ltd., Accra, Ghana
}

\begin{abstract}
:
Management of public debt remains a major economic challenge to governments across the globe. Public debt management is more challenging to countries classified as least developed, less developed, and developing than those termed as developed or advanced economies. Challenges to economic management in some countries led to their description as highly indebted poor countries (HIPC) and low-income countries (LICS). In spite of high interest charges, most governments of developing economies borrow from international financial institutions to support their annual budgets; and to embark on social and institutional infrastructural developments in their respective economies. However, many economic experts and citizens in most of these developing economies have raised concerns about whether or not their governments use the contracted loans for the purposes intended. The purpose of this research was to assess trends in Ghana's debt, and the relative effect of debt on the economy. The present study relied on the quantitative approach to scientific inquiry. Specifically, a cross-sectional design, an example of survey design, was adapted and used in the research. This allowed the researcher to gather relevant research data over a specific period of time. Data required for the research were obtained from secondary sources including text books, journals, research papers, newspaper publications; Google search engine, index mundi, and electronic databases of the bank of Ghana and international bodies such as the international monetary fund, and world economic outlook, among others. Descriptive statistics and regression models were used to describe the research variables; and to evaluate their behavior over the stated time frame in the Ghanaian and other economies. Findings from the research revealed a positive relationship between debt and the economy; the findings revealed debt accounts for about $98 \%$ of the variation in GDP. The study recommended the need for redefinition of debt sustainability and effective implementation of the succession plan principle. Government must ensure relative stability of the cedi against the major foreign currencies to avert the possibility of issuing more notes to settle the same outstanding debts at maturity dates. Intensification of the industrialization campaign is necessary to reduce unemployment rate; and minimize the need for regular borrowing to balance government's annual economic budget.
\end{abstract}

Keywords: Corruption, corruption index, debt, debt to GDP, economic performance, and GDP of economies

\section{Introduction}

Management of public debt remains a major economic challenge to governments across the globe. Public debt management is more challenging to countries classified as least developed, less developed, and developing than those termed as developed or advanced economies. Challenges to economic management in some countries led to their description as Highly Indebted Poor Countries (HIPC) and Low-Income Countries (LICs). The foregoing descriptions affirm the implied countries' inability to honour their debt obligations as they become due. To this end, bilateral lenders, multinational institutions and international financial institutions such the International Bank for Reconstruction and Development (World Bank) and the International Monetary Fund (IMF) are compelled to periodically revise their lending books to write-off some of the debts accumulated by governments of these economies. Initiatives of the foregoing institutions tend to assuage, significantly, the external debt burden of beneficiary economies. Incidentally, Ghana was a beneficiary of the HIPC initiative in the early 2000s. The level of debt forgiveness under the HIPC initiative depends largely on the relative economic strength of the implied country. Thus, debt cancellation under the HIPC programme varies from one economy to the other. Government's planned expenditure is financed through domestic revenue mobilisation including taxes, proceeds from exports, grants from foreign development partners, and borrowing from domestic and international financial institutions. Government's decision to borrow may be vital to effective development of the financial market. Government's resolve to trade in various securities such as short-term Treasury bills, medium- and long-term bonds helps to deepen interactions and to attract more investors to the financial sub-sector of the economy. Government's borrowing creates economic stimulation in the functions of the Monetary Policy Committee (MPC).Corporate bodies use 
government debt as a benchmark for the issuance of private securities such as corporate bonds (Maana, Owino \& Mutai, 2008).

Across the globe, governments are sometimes confronted with budget overruns or deficits. A budget deficit occurs when planned expenditure for a fiscal year exceeds the expected inflows for the same period. Accumulation of budget deficits over given periods results in debt. Thus, government is compelled to borrow to off-set the difference between total inflows (revenues) and outflows (expenditure).Accumulation and sustainability of Ghana's debt relative to gross domestic product (GDP) have been a major concern to some economic analysts and citizens in recent years.

\subsection{Background of the Study}

Discussion in this section proceeded under the following sub-headings: trend in Ghana's debts, recent developments in Ghana's debts, inference; and revenue targets and budget deficit (overrun).

\subsubsection{Trend in Ghana's Debts}

Available statistics from the Bank of Ghana, International Monetary Fund (IMF), World Economic Outlook database, Tradingeconomics.com and Index Mundi, among others, reveal varying trends in Ghana's debts. For instance, Ghana's debt to GDP in 2008 was 33.6\%. In 2010, Ghana's debt to GDP was $46.0 \%$, representing about 36.91\% increase between 2008 and 2010. In 2011, government of Ghana's debt relative to GDP dropped to 43.4\% (from 46.0\% in 2010). Although the Ghanaian economy witnessed a drop-in debt to GDP in percentage terms, there was no reduction in real total debt. Rather, the economy witnessed an increase. For instance, data in Table1 reveal an increase in Ghana's total debt stock from GHф21.3 billion in 2010 to GHф25.5 billion in 2011.

\begin{tabular}{|c|c|c|c|c|}
\hline & $\begin{array}{c}\text { General government net } \\
\text { debt (National currency, } \\
\text { billions) }\end{array}$ & $\begin{array}{c}\text { General government gross } \\
\text { debt (National currency, } \\
\text { billions) }\end{array}$ & $\begin{array}{c}\text { General government } \\
\text { net debt (Percent of } \\
\text { GDP) }\end{array}$ & $\begin{array}{c}\text { General government } \\
\text { gross debt (Percent of } \\
\text { GDP) }\end{array}$ \\
\hline 2003 & 7.9 & 8.0 & 73.6 & 74.2 \\
\hline 2004 & 7.1 & 7.5 & 54.4 & 57.6 \\
\hline 2005 & 6.9 & 7.6 & 43.6 & 47.7 \\
\hline 2006 & 4.1 & 4.9 & 21.9 & 26.2 \\
\hline 2007 & 5.4 & 7.2 & 23.3 & 31.0 \\
\hline 2008 & 9.1 & 10.1 & 30.1 & 33.6 \\
\hline 2009 & 11.9 & 13.2 & 32.6 & 36.1 \\
\hline 2010 & 19.8 & 21.3 & 43.0 & 46.3 \\
\hline 2011 & 23.2 & 25.5 & 38.8 & 42.6 \\
\hline 2012 & 34.5 & 36.1 & 45.8 & 47.9 \\
\hline 2013 & 49.7 & 53.4 & 53.2 & 57.2 \\
\hline
\end{tabular}

Table 1: General Ghana Government Net and Gross Debts 2003 - 2013

Source: International Monetary Fund, World Economic Outlook (WEO) Database, October 2017

The lower debt to GDP ratio recorded in 2011is attributed to increased GDP, relative to total debt accumulated during the period. Recall, in 2011, Ghana recorded a GDP growth rate of 14\%; it was the year in which crude oil was lifted and sold in commercial quantities for the first time. Ghana's debt to GDP witnessed a steady increase from 43.4\% in 2011 to $49.82 \%$ in 2012. Data in Table1depict an increase in government of Ghana's general gross debts from GHф25.5 billion to GH\$36.1 billion, representing about 41.57\% increase; and about 47.9\% of GDP during the period. Data in Table1 show steady increase in general government gross debts from 2007 through 2013.

The trend in general gross debts, in percentage terms, of the government of Ghana from 1990 to 2014 is presented in Figure 1 and Appendix A. Data in Figure 1 and Appendix A corroborate and extend the data in Table1. The data affirm Ghana's debt to GDP in 2014 was about $67.6 \%$; this figure was about $22.63 \%$ higher than the debt to GDP rate (55.1\%) recorded earlier in 2013. Figure 1 reveals significant fluctuations in Ghana's debt to GDP over the 25-year period. A significant increase (123.35\%) in government of Ghana's general gross debts was recorded in the year 2000. A decline $(101.50 \%)$ in Ghana's general gross debts was recorded in 2001.The general gross debts recorded in the years 2000 and 2001 were in excess of government's inflows for those years. Data in Figure 1 depict relative downward decline in general gross debts from 2000 through 2006. General gross debts increased steadily between 2007 and 2010; witnessed a sharp decline in 2011; and surged from 2012 through 2014. 


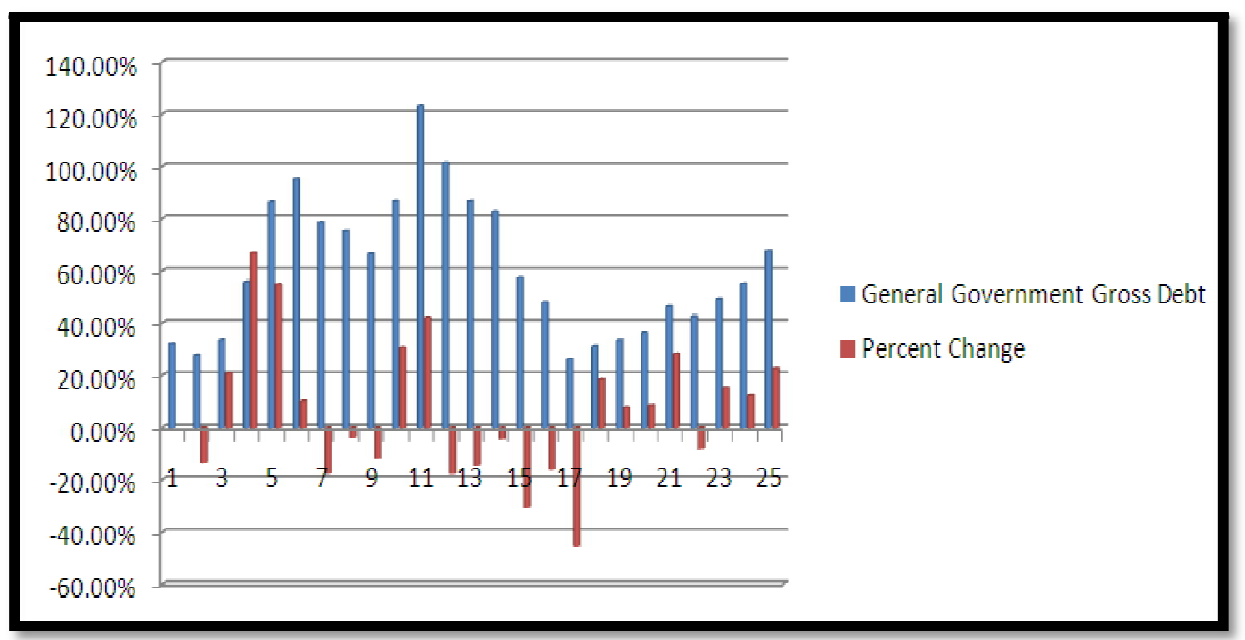

Figure 1: Government of Ghana General Gross Debt 1990 - 2014

Source: International Monetary Fund, World

Economic Outlook Database, April 2015

\subsubsection{Recent Developments in Ghana's Debts}

Macroeconomic and financial data released by the Bank of Ghana revealed government of Ghana's total debt as at December 2015 was GH\$97.2 billion (equivalent to US\$25.6 billion), representing about $72.2 \%$ of GDP in that year. The external debt component was about GH\$57.8 billion, representing about 59.47\% of total debt stock in 2015; and about $43.3 \%$ of GDP in the same year. In 2016, Ghana's debt to GDP was about 73.4\%.In real terms, Ghana's total debt stock as at the end of 2016 was GHф122.6 billion. Ghana's total GDP in 2016 amounted to about GHф167.32 billion (US\$42.69 billion).

At the end of March 2017, an additional GH\$4.5 billion was borrowed ostensibly to settle some debts that were due for repayment. This increased the country's total debt to GHф127.1 billion (GHф122.6 billion + GHф4.5 billion = GHф127.1 billion). The respective external and internal debts amounted to GH\$71.9 billion and GHф55.2 billion, representing 35.3\% and 27.10\% of GDP during the period, that is, March 2017.

Ghana's budget deficit at the end of 2016 was about 9\% of GDP (8.7\% of GDP on cash basis; $10.3 \%$ on commitment basis). Commitment basis means unpaid and outstanding debts during the period. The country's budget deficit for 2017 was estimated at 6.5\%. Ghana's total debt stock as at the end of December 2017 was GHф142.5 billion (US $\$ 32.5$ billion) comprising GH\$75.8 billion (US\$17.2 billion) in total external debtandGHф66.7 billion (US\$15.3 billion)in total domestic debt. Ghana's interest cost and deficit financing for 2017 were projected at GHф27.3 billion.

Between 2016 and 2017, Ghana's domestic debt increased by GHф13.3 billion, representing about 24.91\% increase. Similarly, Ghana's external debt increased by GH $\$ 6.6$ billion, representing about 9.54\% increase during the same period. Ghana's respective external and internal debts were 37.1\% and 32.7\% of GDP in 2017. The country's GDP in 2017 was about GH\$204.16 billion (US\$46.56 billion). Total debt (GHф142.5 billion) as a percentage of GDP (GH\$204.16 billion) in 2017 was about $69.8 \%$ ( (GH\$142.5 billion $\div$ GHф204.16 billion) x 100\% $=69.7982 \%)$. In real Dollar terms, Ghana's GDP growth rate for 2017 could be estimated at $9.07 \%$ ((US\$46.56 billion - US $\$ 42.69$ billion) $\div$ US\$ $\$ 2.69$ billion) x $100 \%=$ $9.0654 \%)$.

\subsubsection{Inference}

The following statistical inferences could be made from available data on Ghana's debt stock: (a) The average government of Ghana's debt to GDP from 1990 to 2014 was about 60.99\%; (b) Ghana recorded an average debt to GDP of about 58.13\% from 1990 to 2015; (c) The average government of Ghana's debt to GDP from 1990 to 2016 was about $57.21 \%$; (d) Ghana's debt to GDP reached an all-time low of about 26.19\% in 2006; (e) Ghana's debt to GDP reached an alltime high of about 123.35\% in 2000; (f) Ghana's debt to GDP witnessed a significant average reduction (about negative 24.54\%) from 2001 through 2006. This was the period during which Ghana qualified for debt forgiveness through the Highly Indebted Poor Countries programme. The debt forgiveness created more borrowing space for the government of Ghana. However, it is important to note borrowing requires due diligence; enough borrowing space does not mean a country should plunge herself into a borrowing spree. It is uneconomical for an economy to borrow excessively at a high commercial rate; (g) similar average reduction (about 11.11\%) in Ghana's debt to GDP was recorded between 1996 and 1998; and (h) Ghana's debt to GDP for 2020 is estimated at 64.96\%.

\subsubsection{Revenue Targets and Budget Deficit (Overrun)}

Ghana's revenue target for 2017 was estimated at GH\$44.9 billion while total expenditure was estimated at GHф58.1 billion, representing 28.6\% of GDP. Total interest cost in 2017 was estimated at GHф14.1 billion. Total budget deficit for 2017 was expected to be financed through domestic and international sources. About GH\$14.6 billion was expected to be financed through domestic borrowing, representing about 7.1\% of GDP while GH\$1.3 billion was expected to be financed through international borrowing, equivalent to $0.6 \%$ of GDP. Ghana's total GDP for 2017 was projected at GH\$203,410,500,000. 


\subsection{Problem Statement}

Debt constitutes a major component of total fund mobilisation sources of advanced and developing economies including Ghana. Due to the relatively low economic strength and repayment capacity of most developing economies, international financial institutions lend to the former at higher commercial rates. In spite of the high interest charges, most governments of developing economies borrow from these international financial institutions to support their annual budgets; and to embark on socio- and institutional infrastructural developments in their respective economies. However, many economic experts and citizens in most of these developing economies have raised concerns about whether or not their governments use the contracted loans for the purposes intended.

It is estimated about US\$116 billion is required to wipe out global hunger while US\$1 trillion is needed to bridge the infrastructural gap across the globe. Similarly, an estimated US\$8.5 billion is required over a seven-year period to eradicate malaria while US\$26 billion is urgently needed to make basic education accessible to children in 46 low- and middle-income economies (United Nations as cited in Thomson, 2017).

However, economies throughout the world lose about US\$2 trillion annually to corruption; this is in excess of the estimated US\$1.151 trillion required to address the global challenges enumerated above. Transparency International (n.d.) reveals about $€ 120$ billion is lost to corruption annually throughout the 27 European Union member states. A similar report released by the African Union in 2013 indicated over US\$148 billion is lost to corruption annually in Africa.

The general business problem is the failure of governments to ensure effective utilisation of fundsmobilised through debt and other sources to accelerate development and growth of their respective economies. Though evidence of this phenomenon exists, there are no scientific inquiries to establish, clearly, the implications of debt for the Ghanaian economy.

The specific business problem is how governments could tap into the rich expertise of available and committed human capital to ensure due diligence and economic utilisation of funds acquired through debt to facilitate national development and growth; and to minimise the incidence of corruption at all levels of their economies. The purpose of this research was to assess trends in Ghana's debt, and the relative effect of debt on the economy.

\subsection{Research Objectives}

\subsubsection{General Objective}

The underlying objective of this study was to examine Ghana's growing debt and its impact on the economy.

\subsubsection{Specific Objectives}

Specifically, the study sought to achieve the following objectives:

- Examine trends in Ghana's debt.

- Evaluate the sustainability of Ghana's debt.

- Assess the impact of excessive debt on the economy.

- Make recommendations for successful utilisation of debt for rapid socio-economic development and growth.

\section{Literature Review}

The current research was conducted under the topic:"Ghana's Growing Debt and Its Implications for the Economy." The main purpose of this study was to assess the level of Ghana's debt and its effect on the economy. This section presents a review of related and existing literature in the research area. A synthesis of literature related to the study is presented in this section. Discussion in this section reveals the relationship between the reviewed literature and research objectives. The main question that underpinned the study was: “What are the implications of Ghana's growing debt for the economy?" Data required for discussion in this section were obtained from text books, journals, research papers, newspaper publications; Google Search Engine, Index Mundi, financial websites such as Tradingeconomics.com; and electronic databases of the Bank of Ghana and international bodies such as the International Monetary Fund, and World Economic Outlook, among others. The following key words were used to generate relevant information and data from the Google Search Engine and other databases: debt, debt to GDP, economic performance, and GDP of economies. The following sub-theme was used in this section: Growing debts in developing and advanced economies. Discussions in this section contributed significantly to the study objective that is, identifying how government could position herself and strategize to avoid crowding-out private sector investors in the economy.

\subsection{Growing Debts in Developing and Advanced Economies}

Constraining public debt to ensure the availability of surplus funds after debt servicing has been a major challenge to many managers of developing and advanced economies (Maana et al., 2008; Mwakima, 2017). The foregoing statement corroborates increased public spending in developing and advanced economies such as Cape Verde, Mozambique, and Congo, United States of America (USA), and the United Kingdom (UK), among others.

A study conducted by Christensen (2005) on 27 sub-Saharan economies revealed increase in interest payments on domestic debts between 1990 and 1994 (49.7\%); and between 1995 and 2000 (51.9\%). The research revealed increase in domestic interest payments relative to government revenues from $10.9 \%$ to $11.5 \%$; and increase in interest payments relative to GDP from $2 \%$ to $2.3 \%$.

Extant literature (Maana et al.; Christensen, 2005; Abbas \& Christensen, 2007; Mussa as cited in Mwakima, 2017) affirms the rising composition of domestic debt in relation to total government debt in many developing economies. This is likely to exert undue pressure on the economy; availability of funds to the private sector for business start-ups and 
expansion may be scarce. To avert this economic challenge, Maana et al. believe leaders of developing economies could adapt cogent debt management strategies to effectively mitigate any adverse effects that the growing debt may have on the economy.

A scientific inquiry conducted by Maana et al. examined the effect of domestic debt on the Kenyan economy for the period 1996 through 2007. The purpose of the study was to make policy recommendations to improve public sector debt management. Data required for the study were obtained from secondary sources including the database of the Central Bank of Kenya. Findings from the study revealed significant increase in domestic debt relative to foreign debt. The study outcome revealed considerable progress in the extension of maturity profile of debts; and government's strong focus on attracting individual and institutional investors. The findings revealed the availability of improved financial structures in Kenya minimised the adverse effect of high public funding through domestic debt on the private sector. Thus, increased domestic borrowing by the Kenyan government did not crowd-out lending by the financial institutions to the private sector. This contradicts findings from earlier study by Christensen (2005) which found a crowding-out effect on lending to the private sector in 27 sampled economies, including Kenya. Perhaps, findings from Christensen's (2005) research prompted the Kenyan government to institute measures to improve on the country's economic management performance; and to improve on the performance of the private sector before the conduct of Maana et al.'s study in 2008.

Emran and Farazi (2008) argue government's decision to engage in domestic borrowing crowds-out the private sector in the long run. They noted government's decision to borrow US\$1 may, in the long run, crowd-out the private sector by about US $\$ 70$ to US\$80. Though the dynamics in Kenya may be different, Emran and Farazi's (2008) findings confirm Christensen (2005) and Osei-Assibey (as cited in Mwakima, 2017) who found a positive relationship between high government domestic borrowing and crowding-out effect on private sector investment.

Abbas and Christensen (2007) sought to analyse optimal domestic levels in low income economies, including 40 subSaharan African economies; and emerging economies. The study focused on the period between 1995 and 2004. Findings from the research revealed economic growth is significantly impacted when the levels of marketable domestic debt expressed as a percentage of GDP are moderate and above. The research outcome revealed debt levels in excess of $35 \%$ of total bank deposits tend to have negative effects on economic growth.

However, Maana et al. believe conclusions drawn on Abbas and Christensen's (2007) research may not be applicable to Kenya since managers of the economy were able to introduce innovative measures to mitigate any adverse effects of growing domestic debts on various sectors, especially the private sector. Maana et al. argue, further, that accelerated development and growth witnessed in the Kenyan economy between 2005 and 2007 were not included in the findings of Abbas and Christensen (2007).

In an attempt to entrench capitalism and encourage free market system, it is imperative for governments not to be seen as competing with the private sector in the financial sub-sector (Abbas \& Christensen, 2007; Christensen, 2005; Maana et al.). Evidently, investors in the private sector may not have the financial and legal muscle to "rub shoulders" with the government in the limited domestic financial environment space. When the government dominates in the domestic financial environment, there may be a crowding-out effect; lending by banks to individuals and corporate bodies may be difficult; and there may be price increases in the economy. This assertion is supported by Ngugi (as cited in Mwakima, 2017)who found a positive relationship between increased domestic borrowing by governments and high interest rates in the open financial markets. Christensen (2005) and Maana et al. affirm massive public sector investment through domestic borrowing crowds-out private sector investment ostensibly through high cost of borrowing from the financial institutions.

Available statistics from the Central Bank of Kenya (as cited in Mwakima,2017) indicated Kenya's national debt during the period was about Kshs 3.77 trillion, representing an increase ofKshs1.88 trillion over the Kshs1.89 trillion recorded in June 2013. One way of reducing government borrowing is by printing new notes. Mussa (as cited in Mwakima, 2017) argues a government's deliberate attempt to print many new notes in an economy would amount to exacting inflation tax on the citizens. Mussa (as cited in Mwakima, 2017) notes government's decision to print new notes to finance development projects may result in high liquidity; and eventual increase in prices of goods and services. The latter may result in dilution of value of money individuals possess. Since individuals may be compelled to consume goods and services at increased prices, they may end up paying for the cost of government's project. For this reason, Mussa (as cited in Mwakima, 2017) believes printing many new notes is a strategy government adapt to ensure citizens pay for the cost of national projects.

A descriptive statistical research conducted by Kangara (as cited in Mwakima, 2017) examined the effect of gross government debt on the Kenyan economy and its related growth. Kangara (as cited in Mwakima, 2017) used regression and correlation models to analyse secondary data obtained from the Central bank of Kenya. Findings from the study revealed a negative relationship between gross government debt and growth of the Kenyan economy. Contrary to the findings from Kangara's (as cited in Mwakima, 2017) study, the current research found a strong positive relationship between debt and Ghana's GDP. However, variations in the research findings may be attributed to differences in institutional and economic management structures in the two African economies.

Susan (as cited in Mwakima, 2017) indicates governments are compelled to borrow when funds mobilised through taxes and sources other than borrowing are not enough to assure a balanced budget or budget surplus. Thus, budget deficits compel governments to borrow to supplement their annual budgets.

Management of total debt relative to gross revenue is not a challenge to developing economies alone; it is equally an economic challenge to developed countries such as the United States of America, the United Kingdom, and Italy, among others. For instance, a report released in 2016 on the United Kingdom's debt showed an increase in the national debt from about $£ 0.5$ trillion in 2005 to over $£ 1$ trillion in 2011. Some financial pundits have attributed the surge in UK's debt to the 
global financial crunch witnessed in 2008. However, UK's total debt stock witnessed further increases in subsequent years; by 2016, the country's total debt was over £1.5 trillion.

The debt in the United Kingdom is not too distinct from the trend in the United States. Available statistics from the National Debt Analysis Report (as cited in Mwakima, 2017) indicated the United States total debt stock as at December 2016 was about US\$18 trillion; by 2017, the figure had surged to over US\$20 trillion.

\section{Research Methodology}

The present study relied on the quantitative approach to scientific inquiry. Specifically, a cross-sectional design, an example of survey design, was adapted and used in the research. This allowed the researcher to gather relevant research data over a specific period of time (Ashley, Takyi \& Obeng, 2016; Creswell, 2009; Frankfort-Nachmias and Nachmias, 2008).Data required for the research were obtained from secondary sources including text books, journals, research papers, newspaper publications; Google Search Engine, Index Mundi, financial websites such as Tradingeconomics.com; and electronic databases of the Bank of Ghana and international bodies such as the International Monetary Fund, and World Economic Outlook, among others. Annual data on gross domestic products and general government gross debts for the period 2003 through 2017; and data on percentage changes in general government gross debts from 1990 to2014were collected and used in the study.

\subsection{Analytical Tools}

Descriptive statistics and regression models were used to describe the research variables; and to evaluate their behaviour over the stated time frame in the Ghanaian and other economies. Measures such as the range and standard deviation were employed to describe the extent of dispersion about the central tendency (Ashley et al., 2016; Creswell, 2009; Frankfort-Nachmias \& Nachmias, 2008); these measures were used to describe the debt to GDP of selected economies relative to Ghana's debt to GDP.

\subsection{Research Variables}

The independent research variable was debt while the dependent research variable was the economy, represented by GDP.

\subsection{Regression Model}

The one-way analysis of variance (ANOVA) was adapted to measure the effect and level of interaction of debt on GDP. The Microsoft Excel analytical software was used in the research. Diagrams and tables were derived from Microsoft Excel to explain the research data.

\subsection{Research Hypotheses}

The study tested the causal relationship between debt and GDP using the following null and research or alternative hypotheses:

- Ho: $\mu 1=\mu 2$; this implies debt has no strong effect on GDP

- $\quad \mathrm{H} 1: \mu 1 \neq \mu 2$; this implies debt has a strong influence on GDP

The major components of national debts are domestic and foreign. On the basis of the above, the following econometric model was formulated for the current research:

$G D P=\beta_{0}+\beta_{1} D D+\beta_{2} F D+\mu_{t}$

Where:

$\mathrm{GDP}=$ Gross domestic product $/$ economy

$\mathrm{DD}=$ Domestic debt

$\mathrm{FD}=$ Foreign debt

$\beta 0=$ Intercept term (Constant)

$\beta 1=$ Coefficient of domestic debt

$\beta 2=$ Coefficient of foreign debt

$\mu \mathrm{t}=$ Error term

\section{Research Findings and Discussions}

\subsection{Debt to GDP Comparisons across Economies}

\subsubsection{Top Ten Economies}

In order to ascertain the magnitude of Ghana's growing debt, it was imperative to evaluate the top ten world economies with the highest debt to GDP in relation to Ghana's debt to GDP.Table2 provides a statistical description of the world's top ten economies with the highest debt to GDP in 2017. They include Japan (253.0\%), Greece (179.0\%), Lebanon $(148.0 \%)$, Italy (131.5\%), Cape Verde (129.2\%), Portugal (126.2\%), Jamaica (122.8\%), Mozambique (120.0\%), Congo (117.7\%), and Singapore (112.0\%).The range of debt to GDP (141\%) of the top ten economies was higher than Ghana's debt to GDP (69.8\%) during the period. Results in Table2 depict respective mean and median of 143.94 and 127.7; and a standard deviation of 42.89 . The latter tells us the extent to which the observations were dispersed around the central tendency. 


\begin{tabular}{|c|c|}
\hline Mean & $\mathbf{1 4 3 . 9 4}$ \\
\hline Standard Error & 13.56270376 \\
\hline Median & 127.7 \\
\hline Mode & \#N/ A \\
\hline Standard Deviation & 42.88903512 \\
\hline Sample Variance & 1839.469333 \\
\hline Kurtosis & 5.026077801 \\
\hline Skewness & 2.210801455 \\
\hline Range & 141 \\
\hline Minimum & 112 \\
\hline Maximum & 253 \\
\hline Sum & 1439.4 \\
\hline Count & 10 \\
\hline Largest(1) & 253 \\
\hline Smallest(1) & 112 \\
\hline Confidence Level (95.0\%) & 30.6809674 \\
\hline
\end{tabular}

Table 2: Top Ten Economies with Highest Debt to GDP

The output in Table2 shows respective Kurtosis and standard error values of 5.026 and 13.563. The standard error value indicates the extent to which the coefficients are significantly different from zero. The skewness of the distribution is 2.211 while the sample variance is 1839.469. Each of the foregoing countries has varied economic strength in terms of gross national product. For example, in 2017, countries such as Cape Verde, Mozambique, Congo, recorded respective GDP of US\$1.7 billion, US\$12.7 billion, and US\$8.10 billion (estimated). Comparatively, Ghana recorded a superior GDP (US\$46.56 billion) in the same year. However, in 2017, Ghana's debt to GDP (69.8\%) was less than the debts to GDP recorded in each of the three foregoing economies (see Table2 and Appendix B). The evidence suggests it may be out of place to argue that Ghana's growing debt, relative to GDP, is unsustainable.

\subsubsection{Selected African Economies}

In 2017, African economies such as Zimbabwe and Mauritania recorded respective GDP of US\$17.5 billion and US\$5.1 billion. During the same period, Sao Tome and Principe and Djibouti recorded respective GDP of US\$0.682 (based on estimated PPP value) and US\$2 billion. The debts to GDP of the foregoing economies are presented in Figure 2 and Appendix C. Debts recorded by Cape Verde (129.2\%), Mozambique (120.0\%) and Congo (117.7\%) were in excess of their respective GDP. Egypt remains the third largest economy in Africa with a GDP of US\$237.1 billion; and debt to GDP ratio of 92.3\%. Though Ghana's GDP (US\$46.56 billion) was relatively high, her debt to GDP (69.8\%) in 2017 waslow compared with rates recorded by Zimbabwe (77.4\%), Mauritania (78.3\%), Sao Tome and Principe (79\%), and Djibouti (86\%) during the same period.

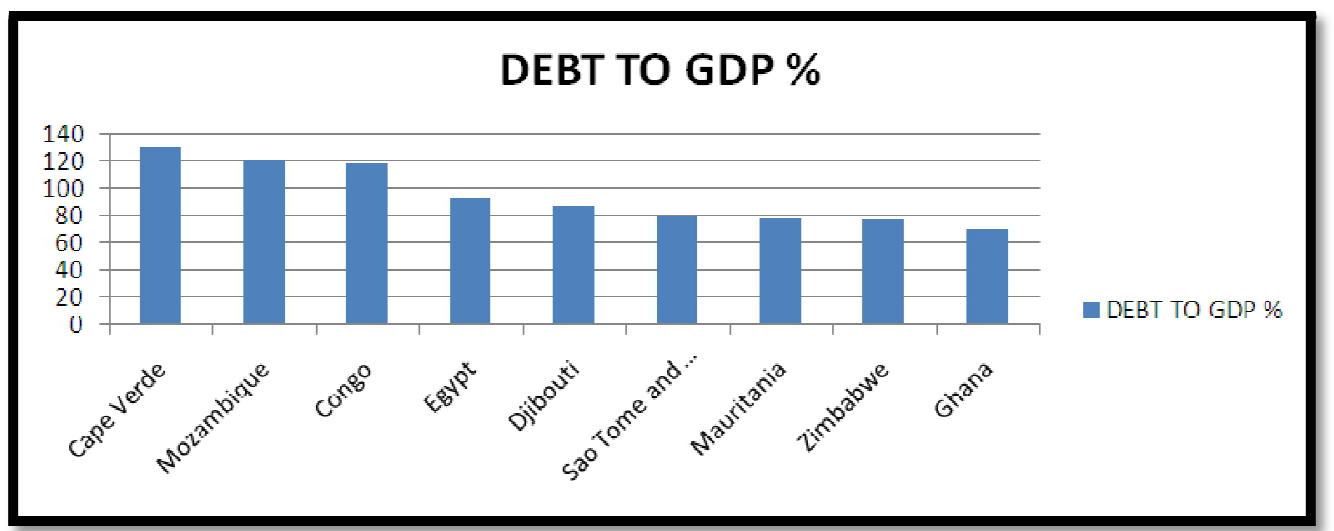

Figure 2: Debt to GDP of Selected African Countries Relative to Ghana's Debt to GDP

A descriptive analysis (see Appendix D) of the data in Figure 2 revealed sample variance of 456.196 and standard deviation of 21.3587. The value for data skewness was 0.556 while the Kurtosis value was -1.822. The respective mean and median for the data were 97.4875 and 89.15. The data showed range of 51.8 and standard error of 7.552.

\subsubsection{United States and Other Economies}

The respective debt to GDP rates of the United States of America (USA), Canada, the United Kingdom (UK), Spain, France, and the Euro Area in 2017 were 105.40\%, 92.30\%, 88.30\%, 99.40\%, 97.00\%, and 88.90\%. In spite of her high debt to GDP rate (105.40\%), as at December 2016, the United States of America remained the largest economy in the world with a real GDP of about US\$18.625 trillion followed by the European Union (US\$16.398 trillion), Euro Area (US\$11.886 trillion), China (US\$11.199 trillion), Japan (US\$4.940 trillion), Germany (US\$3.467 trillion), the United Kingdom (US\$2.648 trillion), and France (US\$2.466 trillion), among others. During the same period, Canada and Spain recorded respective GDP 
of US\$1.530 trillion and US\$1.232 trillion. Ghana's GDP for the same period was about US\$42.69 billion (Trading Economics, 2018). As shown in Figure 3 and Appendix E, comparatively, Ghana had low GDP value; and low debt to GDP rate during the period. For the United States, her debt, US\$19.631 trillion (US\$18.625 trillion +(US\$18.625 trillion x 1.054) $=$ US\$19.63075 trillion), was in excess of her GDP (US\$18.625 trillion) by US\$1.00575 trillion (US\$19.63075 trillion US\$18.625 trillion = US\$1.00575 trillion) during the period. Spain's total debt US\$1.225 trillion (US\$1.232 trillion $\mathrm{x} 0.994$ $=$ US $\$ 1.224608$ trillion) was equivalent to her total GDP during the period.

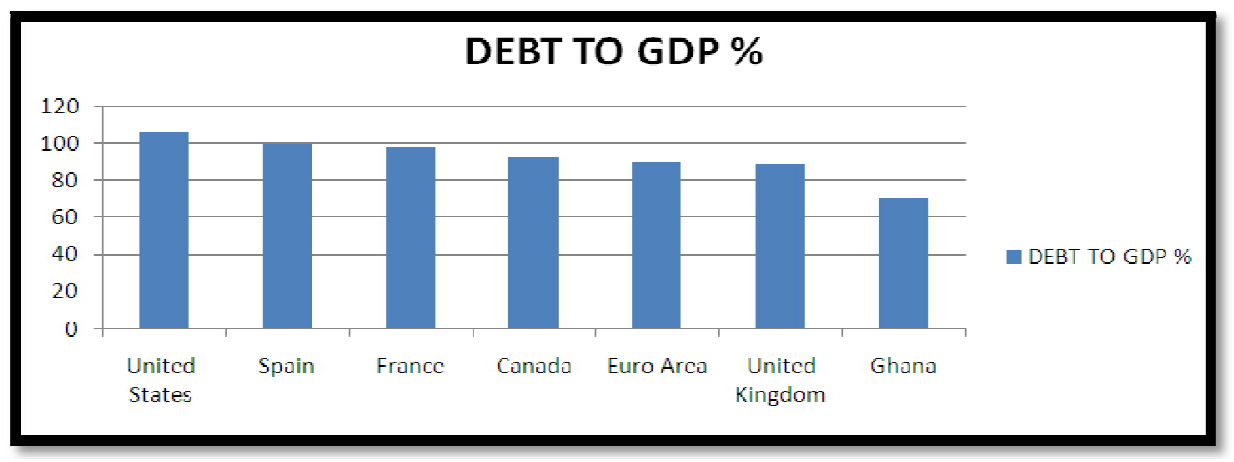

Figure 3: Debt to GDP of the United States and Other Economies

Data in Figure 3 were statistically analysed to explain the values about the central tendency. Results of the descriptive statistics are in Appendix F. The respective mean and standard deviation of the data in Figure 3 were 95.2167 and 6.6427 while the respective range and median were 17.1 and 94.65 . The standard error was 2.712. The respective values for Kurtosis and skewness in the data were - 0.849 and 0.540. The sample variance was 44.126 .

Notwithstanding her relatively high debt to GDP rate(105.40\%), the United States of America remains the economy with the strongest ratings among the major credit rating agencies across the globe. For instance, Moody's, Standard and Poor's (S\&P), and Fitch rate USA at Aaa (Stable), AA+ (Stable), and AAA respectively. Fitch continues to maintain its credit rating of AAA, in spite of warning to the United States government of possible downgrade if the nation's debt ceiling is not reviewed upward. These credit ratings make the United States of America a preferred choice for major lending institutions across the globe.

The United States of America's strong credit ratings in the face of a relatively high debt to GDP rate (105.40\%) affirm the need for Ghanaians to minimise their attention to high debt to GDP rates; and to focus on effective utilisation of funds contracted through loans, in the economy. The United States model implies the economy continues to remain in the "good books" of the major global credit rating agencies (Moody's, Standard and Poor's, and Fitch) due to transactional transparency and overt use of loanable funds for the purposes intended; and that is the way the Ghanaian economy must be managed.

\subsection{Impact of Excessive Debt on the Economy}

Extant research has revealed that the overall impact of high public debt on growth of given economies including Ghana varies considerably, owing to differences in country-specific factors; and other measures such as the ability to sustain debts, ensure macroeconomic stability, prevent financial downward trend or deepening, manage fiscal imbalances, stimulate economic growth through higher private sector participation, prudent management of available resources, diligent use of debts contracted, and favourable political environment, among others.

\begin{tabular}{|c|c|c|}
\hline Year & GDP in Billions of GHC & DEBT in Billions of GHd \\
\hline 2003 & 10.782 & 8 \\
\hline 2004 & 13.021 & 7.5 \\
\hline 2005 & 15.933 & 7.6 \\
\hline 2006 & 18.702 & 4.9 \\
\hline 2007 & 23.226 & 7.2 \\
\hline 2008 & 30.06 & 10.1 \\
\hline 2009 & 36.565 & 13.2 \\
\hline 2010 & 46.004 & 21.3 \\
\hline 2011 & 59.859 & 25.5 \\
\hline 2012 & 75.365 & 36.1 \\
\hline 2013 & 93.357 & 53.4 \\
\hline 2014 & 113.34 & 79.6 \\
\hline 2015 & 134.63 & 97.2 \\
\hline 2016 & 167.32 & 122.6 \\
\hline 2017 & 204.16 & 142.5 \\
\hline
\end{tabular}

Table 3: Ghana's GDP and Debt Values from 2003 to 2017 
Ghana's gross domestic product and debt values for 2003 through 2017 are presented in Table3 and Appendix G.The valuesin Table3 were computed using the following formula:

$\mathrm{GDPt}=((100 \% \div \mathrm{GGGD} \%$ of GDP) $\mathrm{x}$ GGGD $)$

Where:

$\mathrm{GDPt}=$ Gross domestic product for period $\mathrm{t}$

GGGD $=$ General government gross debt

$\%$ of GDP =A percentage of gross domestic product

Ghana's GDP values for 2003 through 2017 were computed using data in Table1 and other sources. Details of computations for the selected years as used in the research analysis are presented in Appendix H. One-way analysis of variance (ANOVA) test was conducted to ascertain the influence of the independent variable(debt) on the dependent variable (GDP).The ANOVA is given by the formula:

$\mathrm{F}=$ MSbetween / MSwithin, in which

MSbetween =SSbetween $/$ dfbetween;

MSwithin =SSwithin $/$ dfwithin

Where:

MS $=$ Mean squared

$\mathrm{SS}=$ Sum of squares

The degrees of freedom (df) under the ANOVA is computed as follows:

degrees of freedom $($ total $)=n-1$

degrees of freedom (between) $=\mathrm{k}-1$

degrees of freedom ( within) $=\mathrm{n}-\mathrm{k}$

Where:

$\mathrm{n}=$ Sample size

$\mathrm{k}=$ Number of groups or levels

\subsection{Results}

\subsubsection{Model Summary}

Results for the ANOVA are presented in Tables 1 through 3. Summary constitutes an important aspect of a regression model. An overall description of the regression model is presented in Table 1 . Values for $\mathrm{R}$, $\mathrm{R}^{2}$, and adjusted $\mathrm{R}^{2}$ are displayed in Table 1. The value of the multiple correlation coefficients between the independent variable and the dependent variable is presented in the $\mathrm{R}$ row. The $\mathrm{R}^{2}$ value in Table 1 tells us the extent to which variability in the dependent variable is accounted for by the independent variable. The $\mathrm{R}^{2}$ value implies debt accounts for about $98.08 \%$ $(0.98076682 \times 100 \%=98.08 \%)$ of the variation in GDP. The results suggest only about $1.92 \%(100 \%-98.08 \%=1.92 \%)$ of the outcome is explained by external random factors.

\begin{tabular}{|c|c|}
\hline \multicolumn{2}{|c|}{ Regression Statistics } \\
\hline Multiple R & 0.99033672 \\
\hline R Square & 0.98076682 \\
\hline Adjusted R Square & 0.979287344 \\
\hline Standard Error & 8.769742197 \\
\hline Observations & 15 \\
\hline \multicolumn{2}{|c|}{ Table 4: Summary Output } \\
\hline
\end{tabular}

One of the measures that determine the generalis ability of the regression model is the adjusted $\mathrm{R}^{2}$. An ideal adjusted $R^{2}$ value is closer to zero or the $R^{2}$ value. The equation used to determine the adjusted $R^{2}$ value $(0.979287344)$ generated by the Microsoft Excel analytical software in Table4 is not specified. In order to test the uniqueness and ability of the equation in the Microsoft Excel analytical software to predict a different sample data selected from the same population, the Stein's equation was applied. This equation illustrates the effectiveness of the regression model in crossvalidating. Stein's formula is given as:

Adjusted $\mathrm{R}^{2}=1-[(\mathrm{n}-1)(\mathrm{n}-2)(\mathrm{n}+1)]\left(1-\mathrm{R}^{2}\right)$

Where:

$$
(\mathrm{n}-\mathrm{k}-1)(\mathrm{n}-\mathrm{k}-2) \mathrm{n}
$$

$\mathrm{R}^{2}=$ Unadjusted value

$\mathrm{n}=$ Number of cases or participants in the study

$\mathrm{k}=$ Number of independent variables in the regression model

To cross-validate our regression model, we computed the adjusted $\mathrm{R}^{2}$ using Stein's equation:

Adjusted $R^{2}=1-[(15-1)(15-2)(15+1)](1-0.98076682)$

$(15-1-1)(15-1-2) \quad 15$

$=1-[(1.07692)(1.08333)(1.06667)](0.01923318)$

$=1-(1.2444409487)(0.01923318)$

$=1-0.0239345568$

$=0.976065443$ 
The adjusted $\mathrm{R}^{2}$ value (0.9761) is not significantly different from the observed value of $\mathrm{R}^{2}(0.981)$ implying that the cross-validity of this regression model is good; the model accurately predicts the same dependent variable from the given independent variable in a different group of participants (Field, 2009, p. 221). The $\mathrm{R}^{2}$ significance was computed using an F-ratio. The ideal F-ratio formula for measuring $\mathrm{R}^{2}$ significance is:

$\mathrm{F}=(\mathrm{N}-\mathrm{k}-1) \mathrm{R}^{2}$ $\mathrm{k}\left(1-\mathrm{R}^{2}\right)$

Where:

$\mathrm{R}^{2}=$ Unadjusted value

$\mathrm{N}=$ Number of cases or participants in the study

$\mathrm{k}=$ Number of independent variables in the regression model

Value for the F-ratio was determined as follows:

$\mathrm{F}=(15-1-1) 0.98076682$

$1(1-0.98076682)$

$=\underline{12.74996866}$

0.01923318

$=662.915267$

Our computations reveal the change in the amount of variance that can be explained gives rise to an F-ratio of 662.9153, which is equivalent to the F-value (662.9153) in Table 5. This F-ratio is significant ( $p=0.000, p<0.001$ ).

\subsubsection{ANOVA}

The ANOVA helps to determine whether or not regression analysis provides better and significant prediction on the outcome than the mean. Data in Table 2 show degrees of freedom (between) of $1(2-1=1)$; degrees of freedom (within) of 13 (15 - 2 =13); total degrees of freedom (df) of 14 (15 - 1 =14), and an F-value of 662.9153.

\begin{tabular}{|c|c|c|c|c|c|}
\hline & Df & SS & MS & F & $\begin{array}{c}\text { Significance } \\
\text { F }\end{array}$ \\
\hline Regression & 1 & 50983.73725 & 50983.73725 & 662.9153 & $\begin{array}{c}1.53677 \mathrm{E}- \\
12\end{array}$ \\
\hline Residual & 13 & 999.8089166 & 76.9083782 & & \\
\hline Total & 14 & 51983.54616 & & & \\
\hline \multicolumn{5}{|c|}{ Table 5: ANOVA }
\end{tabular}

\begin{tabular}{|c|c|c|c|c|c|c|}
\hline & Coefficients & Standard Error & T Stat & P-Value & Lower 95\% & Upper 95\% \\
\hline Intercept & 14.04615167 & 3.124749492 & $\begin{array}{c}4.49512887 \\
6\end{array}$ & $\begin{array}{c}0.00060 \\
3\end{array}$ & $\begin{array}{c}7.29554082 \\
3\end{array}$ & 20.79676252 \\
\hline XVariable 1 & 1.306159455 & 0.050730272 & $\begin{array}{c}25.7471407 \\
4\end{array}$ & $1.54 \mathrm{E}-12$ & $\begin{array}{c}1.19656336 \\
5\end{array}$ & 1.415755544 \\
\hline
\end{tabular}

Table 6: Model Parameters

Data in Table 5 depict the model sum of squares (SSM) value, represented by Regression; the residual sum of squares (SSR) value, represented by Residual; the total sum of squares (SST) value, represented by Total; and the degrees of freedom (df) for each group of squares. The degree of freedom for the SSM is1, comprising the one independent variable (debt). The sum of squares divided by the degrees of freedom gives us the mean squares (MS). That is, $50983.73725 \div 1=$ 50983.73725; and $999.8089166 \div 13=76.9083782$.

\subsubsection{Model Parameters}

Table 6 presents results on the parameters of the regression model. Data in Table 6 show the coefficients, standard error, test statistic, significance, and confidence intervals for the coefficients. The coefficients in Table 3 hint us on the contribution of the independent variable to the regression model. Generally, a positive coefficient connotes a positive relationship between the independent variable and the dependent variable; a negative value symbolizes a negative relationship between the two variables. Results in Table 6 show a positive coefficient value (1.306). This means there is a positive relationship between debt and GDP; the results suggest debt has significant influence on GDP.

The magnitude of the t-test in Table 3tells us the independent variable (debt) had a strong impact on the dependent variable (GDP). A standard error is identified with the coefficients in the table. The standard error shows the extent to which the coefficients would vary in different research samples (Field, 2009). The respective Upper 95\% values for the Intercept and XVariable 1 in Table 3 are 20.79676252 and 1.415755544.

\subsubsection{Report on P -Value and Confidence Interval}

Table 6 depicts $P$ value of 0.000 and positive coefficient value of 1.306. These values are significant at Alpha level $a=0.05$. The table further shows a confidence interval of 1.197and 1.416. The Alpha level, a priori, for this study is $a=$ 0.05.This implies there is a 5 per cent probability that we would be wrong; there is a 5 per cent likelihood that the population mean would not fall within the interval (Bowerman, O'Connell, and Orris, 2004; Frankfort-Nachmias and Nachmias, 2008). However, we are 95\% certain that our conclusions would be right. Again, the Microsoft Excel output in 
Table 2 show degrees of freedom (between) of $1(2-1=1)$; degrees of freedom (within) of $13(15-2=13)$; total degrees of freedom (df) of $14(15-1=14)$, and an F-ratio of 662.9153. These values could be interpreted as:

$\mathrm{F}(1,13)=662.953, \mathrm{p}<0.05$, two-tailed.

\subsubsection{Interpretation and Rejection of Null Hypothesis}

The foregoing results indicate debt has a strong influence on GDP. Therefore, we reject the null hypothesis (Ho: $\mu 1$ $=\mu 2)$, and accept the alternative hypothesis $(\mathrm{H} 1: \mu 1 \neq \mu 2)$ which states that debt has a strong influence on GDP.

\subsection{Implications}

For developing and some lower middle-income economies such as Ghana, the International Monetary Fund (IMF) believes a debt to GDP ratio of $60 \%$ is ideal; any figure beyond the $60 \%$ threshold calls for serious economic concerns. Data in Table3 indicate between 2011 and 2015, Ghana's debt increased by about GHф71.7 billion (GHф97.2 billion GHф25.5 billion = GHф71.7 billion); and from 2016 to 2017, Ghana’s debt increased by about GHф19.9 billion (GHф142.5 billion - GH $\$ 122.6$ billion = GHф19.9 billion). Between November 2017 and December 2017, Ghana's total debt increased by about GH\$3.5 billion (GH\$142.5 billion - GH\$139 billion = GH\$3.5 billion). Government of Ghana’s planned borrowing for the first quarter of 2017 was GH\$17.4 billion; planned borrowing for the same period in 2018 was GHф11.1 billion, representing about GH\$6.3 billion decrease (GHф17.4 billion - GHф11.1 billion = GHф6.3 billion). Per government of Ghana's planned expenditures, GHф2.1 billion, out of the GHф11.1 billion, would be used to meet financial needs while the remaining GH $\$ 9$ billion would be used to pay-off roll over maturities in the current year. It is believed excessive borrowing has the following implications for developing economies including Ghana:

- Poses a risk to the economic security of the country in the long term. For instance, in 2011, the average debt per head based on Ghana's estimated population and total debt during the year was GHф872.99. In 2015, the average debt per head increased to GH\$3,512.81; it surged further to aboutGH $\$ 4,814.20$ (GHф142.5 billion $\div 29.6$ million people $=\mathrm{GH} \$ 4,814.1892)$ per head in 2017. The figures depict about 451.46\% ((GHф4,814.20 - GH\$872.99) $\div$ GH\$872.99) x 100\% =451.4611\%) increase in average debt per head between 2011 and 2017. Thus, as more debt is contracted, the generational debt per head also increases; and if due diligence is not carried out avoidable debts may be contracted for unborn generations.

- Exchange rate volatilities may increase the financial repayment burden of the country. That is, more Ghana Cedis may be required to settle the same outstanding payments in foreign denominated currencies such the United States Dollar or British Pound Sterling or Euro.

- Interests that may accrue on outstanding debts over the lives of the debts may be astronomical. As an example, total interest payments in 2016 and captured in the 2017 budget were about GHф10.770 billion, equivalent to $6.4 \%$ of GDP. Total interest payments as at September 2017 amounted to GHф9.710 billion, equivalent to $4.8 \%$ of GDP. Available data reveal almost one-third of Ghana government's revenue is channeled into interest payments. Until recently, Ghana was denominated among high risk economies with high interest charge on debts contracted.

- Channeling a substantial portion of the nation's inflows into interest and principal debt settlements implies fewer funds available for socio- and institutional infrastructural developments. Capital investment is likely to be severely impacted by the advent of high interest and principal payments. In 2016, the amount spent on capital expenditure was GH\$7.678 billion, equivalent to $4.6 \%$ of GDP, which was less than the GH\$10.770 billion spent on interest payments. Similarly, budgeted capital expenditure for 2017 was GHф5.314 billion, equivalent to 3.2\% of estimated GDP. However, as at September 2017, estimated capital expenditure was GH\$3.696 billion, representing $1.8 \%$ of GDP. One observes actual capital expenditure (GHф3.696 billion) as at September 2017 was less than interest payments ( $\mathrm{GH} \phi 9.710$ billion) during the same period.

\section{Recommendations}

Throughout most developing economies, one observes a common thread, that is, a strong challenge to effective utilisation of available resources including debt to accelerate development and growth. It is equally a challenge to governments to harness the most productive human capital to advance national cause. In view of the foregoing, the following recommendations are made.

- Debt sustainability must be defined to include government's ability to use contracted loans for the purposes intended to accelerate economic development and growth to ease repayment at due dates. Thus, emphasis should neither be on the amount borrowed nor on total debt relative to total GDP. Rather, emphasis should be on proper accountability to loans contracted, judicious and diligent disbursement of contracted funds to ensure equitable socio- and institutional infrastructural developments; and debt servicing at the national level. The foregoing implies government must devise coherent and meaningful strategies to assure sustainability of current and future debts. One of the canons of good lending is purpose. This addresses the question of why the government of Ghana needs the loan. Specifically, the lending institution requires the government of Ghana to state the benefits, viability, legality, necessity, morality or ethics, price and estimated useful life of the purchasing asset (item), and compatibility of the loan with existing activities, among others, before the funds are released. Thus, the underlying objective of loan or debt contracts is explicit and economically reasonable. However, utilisation of the approved loans for the purpose or purposes intended sometimes fizzles into thin air. This is the economic malaise that we must collectively cure as a nation. Model advanced economies such as the United States of America, China, Japan, Great Britain, Germany, among others, enjoy high credit rating not as a result of low debt to GDP ratio, but as a result of judicious and prudent use of debts and other resources at their disposal. As a lower middle-income 
economy, Ghana's must not be too concerned about the quantum of debt to the neglect of provision of essential public and institutional infrastructure needed to create economic stimulation, enhance development and growth; and assure repayment of contracted debts at due dates. This is an effective way of ensuring the country's rapid economic integration; and migration from lower middle income to upper middle-income status. Financial transparency and accountability are pivotal to the realisation of national economic objectives.

- Government must strive to create more fiscal space and less "financial openings" for borrowing. That is, the creation of more fiscal space should not necessarily whet the nation's financial appetite for borrowing; diligent and economic borrowing must always be the watch phrase for the managers of the economy. Diligent and economic borrowing means carefully considering pool of financial alternatives and settling for one that offers the best coupon rate and payment terms for the economy. For instance, if the government of Ghana is able to issue bonds at a coupon rate of $7 \%$ rather than $9 \%, 10 \%$ or $12 \%$, this would translate into cost-savings to the economy; the cost of premium (interest) payments would reduce considerably, especially when the monetary commitment in the bond issuance is high. To create more fiscal space, government must make conscientious effort to shift from the old paradigm of borrowing short to pay short, to borrowing long to pay short. That is, negotiations for loan terms must ensure an extension of repayment periods to enable the government heave a sigh of economic relief in the short- and medium term. For instance, the government of Nigeria recently issued two separate bonds for US $\$ 2.5$ billion each repayable in 15 and 20 years. This is not too distinct from recent bonds issued by the government of Ghana with a maturity period of 15 years. This initiative creates room for strategizing; and meeting the basic needs of the population with minimal and no immediate economic pressures.

- In order to avoid needless additions to the national debt, the principle of succession plan must be fully implemented. This principle urges current and successive governments to diligently review projects started under previous administrations, and carry them through to a logical conclusion before similar or new other major projects are commenced. This would ensure efficiency in national project co-ordination; and effectiveness in national debt management. Through this initiative, government's concerted effort to strategically reduce outstanding national debt; and to legitimately introduce new debt under dire economic circumstances would be essentially rewarded. Further, debts contracted in recent years could be reviewed for renegotiation to reduce the nation's eventual financial burden as already witnessed in some power purchase agreements.

- Current and successive governments must ensure relative stability of the Cedi against major currencies such as the British Pound Sterling, Euro, and American Dollar to avert the possibility of issuing more Cedis to settle the same outstanding debts at maturity dates. Relative stability in the Cedi would ease debt repayments on current and successive governments. Since Ghana remains an import-led economy, constant flow of major currencies such as the American Dollar into the Ghanaian economy is required to tame exchange volatilities that would have negative implications for debts repayments at maturity dates. Establishment of factories in various districts across the country would complement government's efforts at moderating price pressures and minimising foreign exchange volatility in the economy. The performance of the Ghanaian currency (Cedi) against the major trading currencies such as the American Dollar, British Pound Sterling and Euro has been fairly stable in recent times. This relative stability has to be consolidated and improved upon to assure the relative strength of the Cedi in the global financial market.

- Due diligence must dominate all discussions related to debt formation. Government must resort to prudent borrowing. For instance, loans contracted for the purposes of ensuring youth development through the Ghana Youth Entrepreneurial and Employment Development Authority (GYEEDA); accelerating development in the Northern Belt to bridge the development gap between the North and the South through the Savanna Accelerated Development Authority (SADA); acquiring fertilizers for cocoa farms to increase yield and increase the crop's overall contribution to foreign earnings and GDP; constructing new roads and rehabilitating old ones; constructing new classroom blocks; building new hospitals and renovating age-old ones; and constructing new airports and airstrips, among others, must be invested in these projects accordingly. The foregoing implies debts contracted on behalf of the nation must be used for the purposes intended to facilitate their repayment in the medium- and long term.

- Where borrowing becomes inevitable, government delegates must bargain strongly and effectively on behalf of the nation to assure value for money; and avoid undue accumulation of debt. It is not financially profitable to engage in excessive borrowing at commercial rates. Cost of projects must be fairly estimated to avoid the tendency of "willfully" causing financial loss to the state. Ghana's credit ratings in recent times by the world's renowned rating agencies have not been bad; the country has the following credit ratings: Moody's B3 (stable outlook), Standard and Poor's B- (positive outlook), Fitch B (stable outlook), and Trading Economics 31 (stable outlook).The foregoing is perhaps, an affirmation of positives in government of Ghana's economic management and debt creation strides.

- In 2015, the estimated value of non-performing loans (NPLs) in the financial sub-sector of the Ghanaian economy was GH\$4.2 billion. The NPLs value surged to GH\$6.2 billion in 2016, representing about 48\% increase. As at June 2017, the value of NPLs has increased to GH\$8 billion, representing about 29\% increase over the period. It is believed government of Ghana's contribution to the NPLs value is significant; high NPLs affect financial institutions' ability to create more loans to stimulate economic growth, especially through the private sector identified as the engine for rapid economic growth. Therefore, it is imperative for the government to honour her financial obligations to the various financial institutions to facilitate loan creation, ensure economic stimulation, reduce government's indebtedness, and ease the crowding-out effect on the private sector. 
- Government must intensify the industrialisation campaign; government must announce incentives or packages that would stimulate private sector participation in the One District, One Factory programme. Massive private sector participation in the One District, One Factory initiative would create more job opportunities; and increase government's internal revenue inflows through taxes. This would minimise the need for high borrowing to balance government's budget on annual basis; and reduce the level of unemployment in the economy.

- In addition to Point 8 above, government must put measures in place to make the country more attractive to foreign investors, and international financial institutions. One of these measures includes improving on the ease of doing business across the various sectors of the economy. Ghana's global (120th), African (14th), and sub-regional (1st) rankings in the Ease of Doing Business index for 2018 (World Bank Group, 2018) should resonate with the processes individuals and groups go through to finally acquire certificates to establish their businesses. For instance, some investors believe the bureaucratic processes involved in the establishment of a higher academic institution in Ghana are marred by overt frustrations and impediments. These negate the country's acclaimed positive ranking (1st), especially in the West African sub-region. Improved mechanisms in business formation and operation would enhance government revenue mobilisation; and ease government's ability to repay contracted loans at due dates.

- The existing tax systems must be strengthened to assure higher returns to the government's financial coffers. Here, recent steps taken by the Ghana Revenue Authority (GRA) to strategically include many individuals in the tax payment basket through the issuance of free tax identification number (TIN) deserve mention and commendation. GRA's current initiative must be encouraged and sustained by present and future governments to assure realisation of revenue targets. The GRA, in collaboration with the Ministry of Information and the National Commission for Civic Education (NCCE), must continually explain the socio-economic benefits of tax payments to taxpayers to help meet its revenue target for 2018, which is GHф39.8 billion.

- Appointment of individuals as ministers; metropolitan, municipal and district chief executives; and as sub-metro heads must be borne out of academic and professional competence, not based on political vigilantism. Upholding the foregoing qualities in the appointment process would ease supervision at the national level; the national economic management team would have minimal challenges ensuring transparency and accountability to government funds disbursed for development at various levels of the economy. In the early parts of 2018, the Vice President of Ghana, Dr. Mahamudu Bawumia, estimated the liabilities of government ministries, departments and agencies (MDAs) for the fiscal year 2016 at GHф7 billion. However, the liabilities submitted by the MDAs amounted to GHф11.279 billion. This was GHф4.279 billion ( $\mathrm{GH} \$ 11.279$ billion - GHф7 billion = GH $\$ 4.279$ billion) more than the GH\$7 billion estimated by Dr. Mahamudu Bawumia. In percentage terms, the liabilities submitted by the MDAs were about $61.13 \%$ ((GH\$4.279 billion $\div \mathrm{GH} \phi 7$ billion) $\times 100 \%=0.61129 \times 100 \%=61.13 \%)$ in excess of the amount originally estimated by the Vice President. After careful audit of the financial records of MDAs for the fiscal year 2016, the Auditor-General of Ghana rejected GH\$5.479 billion out of the GH\$11.279 billion liabilities submitted. The rejected amount, GH\$5.479 billion, represented about 48.58\% ((GH\$5.479 billion $\div$ GH $\$ 11.279$ billion) $\times 100 \%=0.48577 \times 100 \%=48.58 \%)$ of the total amount submitted by the MDAs. In some cases, funds disbursed by the Finance Ministry to the MDAs are not properly accounted for. Funds lost through this process add up to the stock-pile of debt with no concrete or abstract benefits to the nation. Some of the factors that accounted for these financial improprieties include lack of proper supervision at the national economic management level; appointment of officials with limited or no academic and professional skill and competence, lack of proper records (source documents) to support various transactions, failure on the part of appropriate ministerial heads to act on recommendations of the Auditor-General, among others. To avert these shortcomings, it is imperative for the government to attach strong premium to the suggestions proffered at the beginning of this paragraph. That is, ensuring officials who are appointed to head various MDAs discharge their duties creditably while the Auditor-General is constitutionally empowered to reclaim lost funds, where possible. The AuditorGeneral's Department must be adequately resourced to enhance its ability to embark on quality financial audit to avoid multiple payments on contracts awarded by MDAs and metropolitan, municipal, and district assemblies (MMDAs).

- The social contracts between government leadership and appointees must be strong, effective, measurable, and economically rewarding to all stakeholders with the nation being the ultimate beneficiary.

\section{References}

i. Abbas, A. S. M. \& Christensen, J. E. (2007). The role of domestic debt markets in economic growth: An empirical investigation for low-income countries and emerging markets. International Monetary Fund.

ii. Ashley, E. M., Takyi, H., \& Obeng, B. (2016). Research Methods: Quantitative and Qualitative Approaches to Scientific Inquiry. Accra: The Advent Press.

iii. Babbie, E. (1990). Survey Research Methods (2nd ed.). Belmont, CA: Wadsworth.

iv. Bowerman, B. L., \& O’Connell, R.T. (1990). Linear Statistical Models: An Applied Approach (2nd ed.). Belmont, CA: Duxbury.

v. Christensen, J. E. (2005). Domestic debt markets in sub-Saharan Africa. IMF Staff Papers, 52 (3), 518-538.

vi. Citifmonline.com. (2016). Ghana's debt hits \$25.6 billion. Retrieved http:/ / citifmonline.com/ 2016/ 03/ 21/ ghanas-debt-hits-25-6-billion/ \#sthash.2cKCfhuR.dpuf

vii. Creswell, J. W. (2009). Research Design: Qualitative, Quantitative, and Mixed Methods Approaches (3rd ed.). Thousand Oaks, CA: Sage Publications. 
viii. Dogbevi, E. K. (2016). Finance minister admits Ghana's public debt above sustainable levels. Retrieved from https:/ / www.ghanabusinessnews.com/ 2016/ 07/ 26/ finance-minister-admits-ghanas-public-debt-abovesustainable-levels/

ix. Dordunoo, C. K. \& Nyanteng, V. K. Overview of Ghanaian Economic Development. In V. K. Nyanteng. (Ed.). (1997). Policies and Options for Ghanaian Economic Development. Accra: The Institute of Statistical and Social Research, University of Ghana.

x. Emran, S. M. \& Farazi, S. (2008). Government borrowing and private credit: Evidence from developing countries. Institute of International Economic Policy, Working Paper Series, 2009-9.

xi. Ewusi, K. (2013). Policies and options for Ghana's economic development. ISSER.

xii. Field, A. (2009). Discovering Statistics Using SPSS(3rd ed.). London: Sage.

xiii. Frankfort-Nacmias, C. \& Nachmias, D. (2008). Research Methods in the Social Sciences (7th ed.). USA.: Worth Publishers.

xiv. Frimpong, D. (2017). Ghana's public debt hits GH\$127.1 billion. Retrieved from http:/ / www.pulse.com.gh/ bi/ finance/ 2017-debt-rate-ghanas-public-debt-hits-gh-127-1-billion-id6717697.html

xv. Ghana Data Portal. (2017). General government gross debt: Ghana. Retrieved from http:/ / ghana.opendataforafrica.org/ ecvmfkc/ government-debt?country=Ghana

xvi. Greene, W. H. (1993). Economic Analysis. London: Prentice-Hall International.

xvii. Hansen, M. H., Hurwitz, W. N. \& Madow, W. G. (1953). Sample Survey Methods and Theory. NY: Wiley.

xviii. Index Mundi. (2018). External debt stocks, public and publicly guaranteed (PPG) (DOD, current US\$). Retrieved from https:/ / www.indexmundi.com/ facts/ indicators/ DT.DOD.DPPG.CD

xix. Index Mundi. (2018). Ghana public debt. Retrieved from https:/ / www.indexmundi.com/ ghana/ public debt.html

xx. Knoema.com. (2018). World GDP ranking 2017/GDP by country/data and charts. Retrieved from www.knoema.com/ nwnfkne/ world-gdp-ranking

xxi. Kontoh, E. K. (2016). How much you owe as a Ghanaian: Implications on balooning Gov't debt. Retrieved from http:/ / citifmonline.com/ 2016/ 04/ 04/ how-much-you-owe-as-a-ghanaian-implications-on-balooning-govt-debt/

xxii. Maana, I., Owino, R., \& Mutai, N. (2008). Domestic debt and its impact on the economy - The case of Kenya. Annual African Econometric Society Conference, Pretoria, South Africa.

xxiii. Mwakima, M. M. S. (2017). The Impact of Government Borrowing on Private Sector Credit in Kenya. A Dissertation Submitted to the School of Business, Univ. of Nairobi, Kenya.

xxiv. Schwab, K. (2017). A call for responsive and responsible leadership. Retrieved from https:/ / www.weforum.org/ agenda/ 2017/ 01/ a-call-for-responsive-and-responsible-leadership

xxv. Thomson, S. (2017). We waste $\$ 2$ trillion a year on corruption. Here are four better ways to spend that money. Retrieved from https:/ / www.weforum.org/ agenda/ 2017/01/ we-waste-2-trillion-a-year-on-corruption-here-are-fourbetter-ways-to-spend-that-money/

xxvi. Trading Economics. (2016).Ghana government debt to GDP. Retrieved from http:/ / www.tradingeconomics.com/ ghana/ government-debt-to-gdp

xxvii. Trading Economics. (2018). Country list government debt to GDP. Retrieved from https:/ / tradingeconomics.com/ country-list/ government-debt-to-gdp

xxviii. Trading Economics. (2018).Ghana government debt to GDP: 1990-2018. Retrieved from https:/ / tradingeconomics.com/ ghana/ government-debt-to-gdp?continent=america

xxix. Transparency International. (n.d.). Corruption statistics - Transparency International UK. Retrieved from http:/ / www.transparency.org.uk/ corruption/ corruption-statistics/

xxx. World Bank Group. (2018). Doing Business 2018: Reforming to Create Jobs. World Bank Group. 


\section{Appendix}

\begin{tabular}{|c|c|c|}
\hline Year & General Government Gross Debt & Percent Change \\
\hline 1990 & $31.98 \%$ & $-13.38 \%$ \\
\hline 1991 & $27.70 \%$ & $20.82 \%$ \\
\hline 1992 & $33.47 \%$ & $66.77 \%$ \\
\hline 1993 & $55.81 \%$ & $54.92 \%$ \\
\hline 1994 & $86.47 \%$ & $10.04 \%$ \\
\hline 1995 & $95.15 \%$ & $-17.58 \%$ \\
\hline 1996 & $78.42 \%$ & $-3.93 \%$ \\
\hline 1997 & $75.34 \%$ & $-11.81 \%$ \\
\hline 1998 & $66.44 \%$ & $30.47 \%$ \\
\hline 1999 & $86.69 \%$ & $42.29 \%$ \\
\hline 2000 & $123.35 \%$ & $-17.71 \%$ \\
\hline 2001 & $101.50 \%$ & $-14.62 \%$ \\
\hline 2002 & $86.66 \%$ & $-4.44 \%$ \\
\hline 2003 & $82.81 \%$ & $-30.77 \%$ \\
\hline 2005 & $57.33 \%$ & $-16.22 \%$ \\
\hline 2006 & $48.03 \%$ & $-45.47 \%$ \\
\hline 2007 & $26.19 \%$ & $18.38 \%$ \\
\hline 2008 & $31.01 \%$ & $7.70 \%$ \\
\hline 2009 & $33.40 \%$ & $8.48 \%$ \\
\hline 2010 & $36.23 \%$ & $28.27 \%$ \\
\hline 2011 & $46.47 \%$ & $-8.43 \%$ \\
\hline 2012 & $42.55 \%$ & $15.33 \%$ \\
\hline 2013 & $49.08 \%$ & $12.25 \%$ \\
\hline 2014 & $55.09 \%$ & $22.63 \%$ \\
\hline & $67.56 \%$ & \\
\hline
\end{tabular}

Table 7: Government of Ghana General Gross Debt 1990 - 2014

Source: International Monetary Fund, World Economic Outlook Database, April 2015

\begin{tabular}{|c|c|}
\hline Country & Debt To Gdp \% \\
\hline Japan & 253 \\
\hline Greece & 179 \\
\hline Lebanon & 148 \\
\hline Italy & 131.5 \\
\hline Cape Verde & 129.2 \\
\hline Portugal & 126.2 \\
\hline Jamaica & 122.8 \\
\hline Mozambique & 120 \\
\hline Congo & 117.7 \\
\hline Singapore & 112 \\
\hline Ghana & 69.8 \\
\hline
\end{tabular}

Table 8: Top Ten Economies with Highest Debt to GDP Relative to Ghana's Debt to GDP

\begin{tabular}{|c|c|}
\hline Country & Debt To Gdp \% \\
\hline Cape Verde & 129.2 \\
\hline Mozambique & 120 \\
\hline Congo & 117.7 \\
\hline Egypt & 92.3 \\
\hline Djibouti & 86 \\
\hline Sao Tome and Principe & 79 \\
\hline Mauritania & 78.3 \\
\hline Zimbabwe & 77.4 \\
\hline Ghana & 69.8 \\
\hline
\end{tabular}

Table 9: Debt to GDP of Selected African Countries Relative to Ghana's Debt to GDP 


\begin{tabular}{|c|c|}
\hline Mean & $\mathbf{9 7 . 4 8 7 5}$ \\
\hline Standard Error & 7.55145297 \\
\hline Median & 89.15 \\
\hline Mode & \#N/A \\
\hline Standard Deviation & 21.35873441 \\
\hline Sample Variance & 456.1955357 \\
\hline Kurtosis & -1.821775089 \\
\hline Skewness & 0.555495002 \\
\hline Range & 51.8 \\
\hline Minimum & 77.4 \\
\hline Maximum & 129.2 \\
\hline Sum & 779.9 \\
\hline Count & 8 \\
\hline Largest(1) & 129.2 \\
\hline Smallest(1) & 77.4 \\
\hline Confidence Level (95.0\%) & 17.85634882 \\
\hline
\end{tabular}

Table 10: Descriptive Stats: Selected African Economies with High Debt to GDP

\begin{tabular}{|c|c|}
\hline Country & Debt To Gdp \% \\
\hline United States & 105.4 \\
\hline Spain & 99.4 \\
\hline France & 97 \\
\hline Canada & 92.3 \\
\hline Euro Area & 88.9 \\
\hline United Kingdom & 88.3 \\
\hline Ghana & 69.8 \\
\hline
\end{tabular}

Table 11: Debt to GDP of the United States and Other Economies

\begin{tabular}{|c|c|}
\hline Mean & $\mathbf{9 5 . 2 1 6 6 6 6 6 7}$ \\
\hline Standard Error & 2.711877169 \\
\hline Median & 94.65 \\
\hline Mode & \#N/ A \\
\hline Standard Deviation & 6.642715308 \\
\hline Sample Variance & 44.12566667 \\
\hline Kurtosis & -0.848948326 \\
\hline Skewness & 0.539535254 \\
\hline Range & 17.1 \\
\hline Minimum & 88.3 \\
\hline Maximum & 105.4 \\
\hline Sum & 571.3 \\
\hline Count & 6 \\
\hline Largest(1) & 105.4 \\
\hline Smallest(1) & 88.3 \\
\hline Confidence Level (95.0\%) & 6.971102188 \\
\hline
\end{tabular}

Table 12: Descriptive Stats: Debt to GDP of the United Sates and Other Economies 


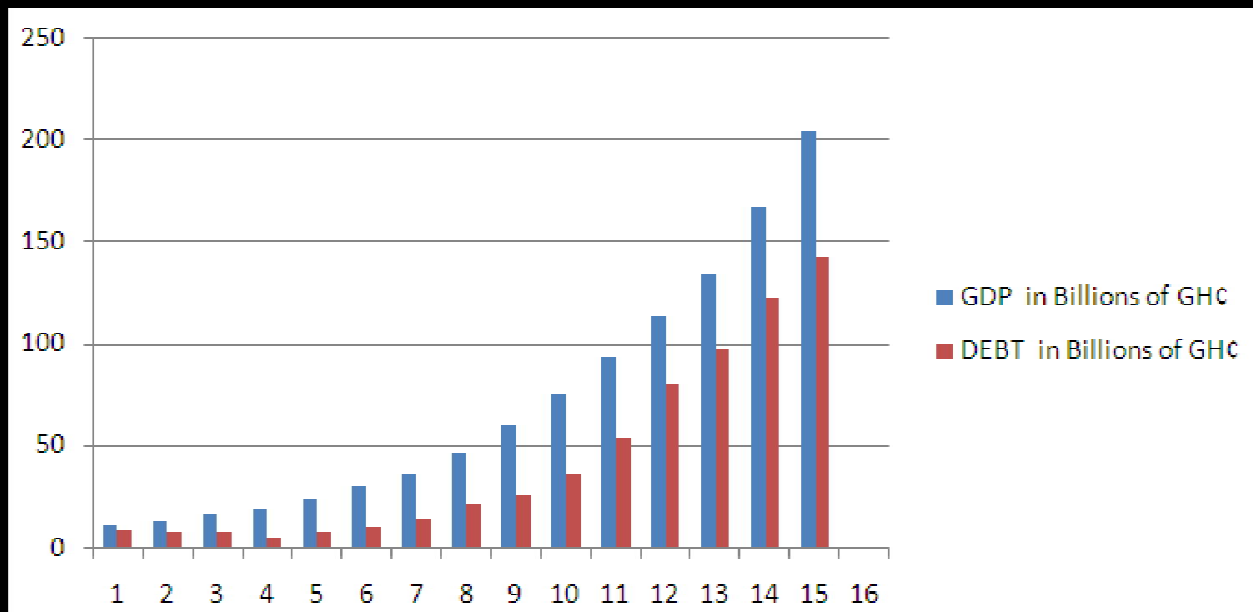

Figure 4:Ghana's GDP and Debt Values from 2003 to 2017

Formula for Determining GDP

GDPt $=((100 \% \div$ GGGD $\%$ of GDP $) \times$ GGGD $)$

Where:

GDPt $=$ Gross domestic product for period $\mathrm{t}$

GGGD $=$ General government gross debt

$\%$ of GDP $=$ A percentage of gross domestic product

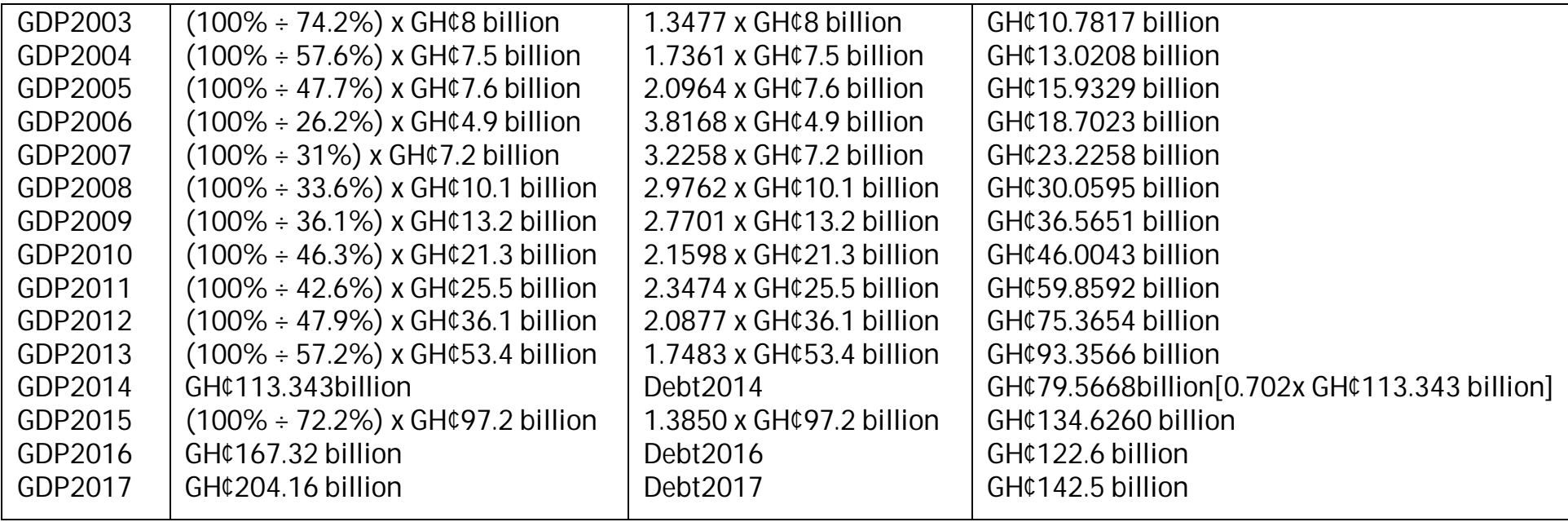

Table 13: Using Data in Table1 and Other Sources, Ghana's GDP for 2003 through 2017 were computed as Follows 